\title{
ANCIENT GREEK MILITARY THEORY AND PRACTICE. AENEAS TACTICUS (II)
}

\author{
Dana DINU \\ University of Craiova, Romania \\ dinudana9@yahoo.com
}

\begin{abstract}
The attention still enjoyed today by Aeneas' treatise on how to withstand a siege is not merely due to its antiquity. Many of the military principles and practical instructions it conveys are still valid. In addition to these, a closer examination opens a broader insight into the Greek city of the fourth century $B C$ than that for which the manual was originally designed, for scholars found many interesting historical, political, social, ethnographic, and linguistic aspects scattered throughout the text. The aim of this paper is firstly, to emphasize the way in which the ideas and instructions of Aeneas Tacticus are articulated in a rigorous and clear plan and, secondly, to draw attention to some of the issues which are not specific to the military, but began to be considered relevant to the overall picture of the treatise.
\end{abstract}

Keywords: Aeneas Tacticus, military treatise, tactics, siege, ancient Greek city.

\section{Introduction}

In his treatise, Aeneas Tacticus provides a rigorous plan, developed into sequences of possible events accompanied by defence instructions that have the logic of what he deems useful for the readers. It goes without saying that it is up to each commander conducting defence operations in his city to adapt these instructions and apply them to the reality of the situation in which they find themselves. For some scholars, the manual reflects the experience and military leadership qualities of its author. Thus, in the Introduction to the volume Aeneas Tacticus, Asclepiodotus, Onasander it is considered that "Aeneas gives abundant evidence of first-hand acquaintance with his subject and an experience in military operations which, though extensive, is almost wholly confined to the geographical limits of the Peloponnesus and the western coast of Asia Minor (with the adjacent islands). He seems, accordingly, to have served in these two fields, and as few Asiatic Greeks were drawn to the Peloponnesus, while thousands of
Peloponnesians, and especially Arcadians, served as condottieri in the East, it can hardly be doubted that Aeneas was a Peloponnesian who had seen service in the Aegean and in Asia Minor" [1]. Not the same opinion is shared by Herbert Fischer who says that: Primum denegamus compositum esse libellum eo animo ut utilitatem ferret iis, qui profecto obsidentur. (In the first place, we deny that the manual was written with the intention to provide help to those who are really besieged). [2]. This point of view is shared by Louis Fischer in the review of Méridier book: “L'ouvrage d'Énée n'a pas·été écrit par un chef militaire désireux de faire profiter de son expérience les habitants d'une ville assiégée; ce n'est pas un traité de tactique, mais des instructions sur la discipline militaire destinées aux écoles" [3]. For his part, T. Hudson Williams is reserved in providing the author with extensive military experience: "The author was certainly not accustomed to operations on a large scale nor was he a member of an imperial state like Athens; of significance, perhaps, is the 
omission of all reference to an acropolis, and the constant assumption of the close proximity of the sea. Sauppe thinks it possible that he lived on the coast of the Hellespont or the Pontus; the author makes frequent mention of places in those regions and seems to be personally acquainted with them" [4]. But L. W. Hunter, in the review of the same work of Fischer which I have already mentioned, has provisionally expressed his disagreement on this point: "Finally, I must at present express a provisional disagreement with the startling proposition in the Appendix (p. 66) [...] and his opinion (unless I misunderstand him) that the treatise was used as a series of lectures on Tactics (Schulvorträge) to students for a military diploma (or was it as a school reading book?)" [5]. However, the highly rigorous organization of the material shows a well-ordered and familiar mind with the issues of war through direct experience, and Isaac Casaubon, the first publisher and translator in Latin of Aeneas the Tactician is confident that military experts will appreciate him precisely for the information he provides and their usefulness: Periti rerum, quorum est de huiusmodi scriptis ferre sententiam, si hunc Aeneae com-mentariolum legerint, non dubitabunt, scio, pronuntiare, ab auctore profectum, qui earum rerum, quibus de scribebat, magnum usum habebat, et iudicio non mediocri valebat. (The experts who have the capacity to pronounce on such writings, when they read this commentary of Aeneas, will not hesitate to say, I am sure, that the author who wrote of these things has a great deal of experience of the things he wrote and that he has a great intelligence.) [6].

\section{General design and aims of the treatise}

Aeneas has a well-structured overall view of the situation a city threatened by the siege must cope with. The measures he provides are concrete and comprehensive, meticulous and cautious, especially because they are inspired by real situations and most likely lived by himself. The main objective is to avoid unexpected and subversive events, so that the author is trying to inventorize all the possibilities of being attacked by the enemy, and to propose solutions to neutralize them. As a means of drawing attention to a potential danger, he often uses the illustrative and persuasive power of the example extracted from historical reality.

The general theme of the manual is divided into sub-topics which form the contents of the 40 chapters. The author does not abruptly approach technical issues, but makes a brief introduction that highlights the difference between the wars outside the city, in foreign lands, in which are exposed to dangers only those who are part of the expedition, while the city, family and all values remain at home safely, and the defensive wars, in which all these values are exposed to danger and their salvation depends on the ability to decisively and permanently repel the enemy and prevent him from attacking again. The introduction is short, highly concise and striking in its ideas and formulations.

\subsection{Content structure}

A conspectus of the treatise present in the first edition, both in the original Greek text and in the Latin translation of its editor Is. Casaubon is very old, presumably going back beyond the $3^{\text {rd }}$ century $\mathrm{AD}$, given that Julius Africanus had knowledge of it (Non pauca ex Aenea ad verbum repetit Iulius Africanus in Cestis, Casaubono observante. In his Kestoi Julius Africanus repeated verbatim much of Aeneas). But it is very unlikely that this conceptus belonged to Aeneas.

At a closer look and structured on chapters, looks as follows: I. Organizing the troops. II. How to secure open spaces III. How to act if fear spreads among citizens. IV. On signals. V. On gatekeepers. VI. On outposts by day. VII. Calling back within the city walls of those citizens working in the field. VIII. How to render difficult and cumbersome the enemy access to rural areas. IX. On how to deter the enemy from attacking. X. Orders that citizens must comply with. XI. On plotting. XII. 
Precautionary measures with regard to allies. XIII. Preserving the mercenary units. XIV. How to secure consensus among the besieged. XV. Ordering expeditions against the attackers outside the city walls. XVI. Alternative methods for organizing expeditions to help rural areas against invaders. XVII. Precautionary measures during festivals and funerals outside the city. XVIII. Measures to prevent possible treachery of the gatekeeper at night. XIX. How to noiselessly cut a bar or a latch. XX. Measures to avoid tampering with the bars and locks of the city gates. XXI. Preparing siege tools and other matters. XXII. Positioning the night guards. XXIII. Precautions to be observed in making secret sallies at night. XXIV. On passwords. $X X V$. Signs issued in addition to passwords. XXVI. On the watch rounds at the foot and on the wall of the city. XXVII. On prevention of panic. XXVIII. On securing the gates. XXIX. On bringing illegal weapons into the city. XXX. Precautions regarding arm sales and access to seized arms. XXXI. Ways for sending secret messages. XXXII. Methods of repelling enemy assaults. XXXIII. Means of setting fire to the machines of the enemy. XXXIV. Materials for extinguishing fire. XXXV. Flammable materials. XXXVI. Ways for preventing the ladder from being placed against the wall. XXXVII. Methods to locate the tunnels dug by the enemy and measures to prevent them from digging tunnels. XXXVIII. Ways to keep away the enemy from the city. XXXIX. Setting traps against the enemies. XL. Stratagems to defend the city with few people.

The last chapter is titled Classis Ordinatio, "The organization of the fleet". Although it seems incongruous with the rest, the presence of this aspect makes sense, because the Greek cities were mostly near the sea and could equally be besieged from sea and from land, as Casaubon mentions in the footnote to this title, showing that some other authors deliberately introduced this topic when discussing the siege of a city. W. A. Oldfather in the Introduction to the volume that I already cited [1] proposes a division of the subject into six major ideas, as follows:" 1 . On selecting and disposing troops and on preparing positions in and about the city for facilitating the defence (1-10.24). 2. On maintaining morale and discipline and general measures for thwarting treachery and revolution (10.25-14 et passim). 3. On repelling sudden forays (15-16.15). 4. On checking, at a distance from the walls, the advance of a foe, and on taking special precautions regarding religious processions outside the city walls and treachery at the gates (16.16-20). Chapter 21 is transitional. 5. On guarding the walls by night and by day and preventing arm smuggling to revolutionary factions and their direct communication with the foe (22-31). 6. On means to face the actual assault of the foe upon the fortifications (32-40). These practical and technical indications are described în detail and with the complexity of a real confrontation.

Aeneas does not neglect a very important aspect of the siege situation that may compromise even the best logistic and military organization, namely the psychological aspect. With or without intent and forced by the circumstances, under the stress of a prolonged siege, people can act against the interests of the city. Aeneas considers, for example, the possibility of relatives of citizens of the city being taken hostage by the enemy and points out that this can be very dangerous because it affects the desire to fight for the common salvation and undermines the effectiveness of the defence measures. Other issues pertain to the field of mass psychology, to the surveillance of the supervisors, in other words to the counterintelligence, to the management of panic situations, to the ways of cultivating and maintaining among the population the sense of attachment to the common interest, to the attitude of civilians against troops during the attack.

About the security of the circulation of the information and preventing interception, 
Aeneas makes numerous recommendations. He describes no less than eighteen ways to send secret and encrypted messages. He is the first author to describe in detail the steganography or hidden writing method, consisting of encrypting a message by hiding it within a normal uncoded message. Aeneas places great emphasis on preventing the possibility of any communication with the enemy. The success of an operation depends to great extent on the ability to design in detail all the actions which must remain hidden from the foe. A real and fairly frequent threat to be taken into account was the enemy penetrating inside the city through various means, either during the day or at night. Therefore, he considers drastic measures such as the rigorous verification of the identity of all those entering the city. The threat from the inside is considered the worst, either because of the infiltration of the enemy, or the betrayal of some members of the city, which is even more serious. Aeneas talks about the possibility of conspiracies to overthrow the leadership of the city or conspiracies to smuggle weapons into the city. Therefore, he proposes preventive measures such as prohibiting meetings, censoring letters, keeping an eye on the inns, expulsion or arrest of foreign suspects, putting off lights to prevent detection, including economic measures such as wealth taxation, suspending profit, but granting bonuses for those importing food and weapons.

The commander of the operations should keep under his direct, severe and permanent control most of the activities, such as digging ditches or codifying messages. $\mathrm{He}$ shall take measures to ensure fire protection, to secure the gates and walls of the city, to protect the import of weapons etc. Because during any siege the most threatening situations are caused by betrayal, conspiracies or revolutions instigated by the enemy - even more dangerous than direct confrontation, because it can call into question the very existence of the city - Aeneas pays special attention to prevention and permanently insists on precautionary measures. The enemy will not hesitate to create opportunities to undermine the city or to take advantage of situations when the vigilance of the defenders might decrease.

A very effective form of defence is the concord of the citizens, homonoia, and the trust between them. Their absence may create a situation of stasis favourable to those who conspire to change the constitution of the city. In chapter XVII, Aeneas warns against the dangers that may arise during the various ceremonies and gives the example of the city of Argos, where there was a revolution of the nobility against the people, just in the course of a religious festival frequented by young people carrying weapons and which involved movements outside of the city walls.

\section{2. Historic value of Aeneas' treatise}

In addition to the prospect of military conflict between cities, this handbook also provides an insight into the history of ancient Greece, particularly into the life in rather small towns and their related communities. Thus, we can see how they design strategies to defend their city, what they stand for, what are the living conditions in small communities during the siege, what is the technology available to them and other aspects of life in wartime, but also in peacetime or in between attacks, as people were trying to continue their religious, cultural, economic and political life, even in conditions of war. The history of Greek cities in the fourth century BC, when the author writes this treatise and when most of the illustrative episodes for his precepts take place, is deeply marked by crises, pressure for social changes, political conspiracies and instability inside cities and competition between the cities. Aeneas does not express any political position towards a form of government, although some commentators have speculated that he might have been inclined to adopt a democratic attitude, others, on the contrary, to oligarchic sympathies. 


\section{Conclusions}

The manual of Aeneas has enjoyed a very good reception since antiquity. It was immediately widely spread and became known and appreciated by a commander of the value of Pyrrhus, the king of Epirus, whose adviser Cineas compiled an epitome which in its turn circulated for a long time. A long series of ancient and medieval authors used his precepts and he became mandatory bibliography for authors of military treatises. An author as important as Polybius read and quoted him in his work. Aeneas is chronologically succeeded by Onasander, Aelianus, Polyaenus, Julius Africanus and other Greek authors - some of them from the Byzantine period - and by a few Romans writers from the late period of the Roman Empire and the Medieval Age. The text is preserved in five manuscripts, the oldest dating from the tenth century. Casaubon introduced it into the era of printing and opened the door to its modern reception. It begins to be perceived from a more complex and interesting perspective that passes from the content of a military textbook to philological aspects. The nineteenth-century philologists applied unduly rigid methods of textual criticism, suspecting massive interpolations and thus undermining Aeneas' authenticity. In the following century, another philologist set to work like an archaeologist and dug into the text no less than twelve layers deep in search of a supposed "Proto-Aeneas". The deepening of our knowledge about the Greek language spoken in the period when the manual was written explains some questionable linguistic aspects of the Aenean studies. Over the last few decades, the emphasis is placed on capitalizing on other resources offered by the text. Thus, regardless of the nature of the interest of those who studied his text, Aeneas enjoyed attention and respect spanning nearly two and a half millennia, and has the privilege of being the author of the oldest treatise on military art preserved until today.

\section{References}

[1] Aeneas Tacticus, Asclepiodotus, Onasander, Translated by Illinois Greek Club, Loeb Classical Library, Cambridge MA, Harvard University Press, 1986, p. 5, note 4.

[2] Fischer, Herbert, Quaestiones Aeneanae. Pars I, Dresdae, ex officina Teubneriana, MCMXI, Appendix, p. 66.

[3] Méridier, Louis, Herbert Fischer. Quaestiones Aeneanae, pars I, Revue des Études Grecques, tome 28, fascicule 126, 1915, pp. 66-67 http://www.persee.fr/doc/reg_0035039_1915_num_28_126_6830_t1_0066_0000_4

[4] Hudson Williams, T., The Authorship of the Greek Military Manual Attributed to 'Aeneas Tacticus', The American Journal of Philology, Vol. 25, No. 4 (1904), pp. 390405.

[5] Hunter, L. W., Fischer's Quaestiones Aeneanae, The Classical Review, Vol. XXVIII, No. 5, 1914, pp. 169-170.

[6] Aeneae Tactici Commentarius de toleranda obsidione, Graece ad codices Mss. Parisienses et Mediceum recensuit, versionem Latinam et commentarium integrum Is. Casauboni, Notas Iac. Gronovii, G. H. Koesii Caspari Orellii aliorumque et suas adiecit Io. Conradus Orellius, Lipsiae, in Libraria Weidmannia, MDCCCXVIII, Praefatio, p. 8. 